\title{
Comparison of Serum Inhibin B and Follicle-Stimulating Hormone (FSH) Level between Normal and Infertile Men in Yaoundé
}

\author{
Tchoula Mamiafo Corinne $\mathbb{D}^{1},{ }^{1}$ Pieme Constant Anatole, ${ }^{2}$ and Ngogang Yonkeu Jeanne ${ }^{2}$ \\ ${ }^{1}$ Department of Biochemistry, Faculty of Sciences, University of Yaoundé I, PB 812 Yaoundé, Cameroon \\ ${ }^{2}$ Department of Biochemistry, Faculty of Medicine and Biomedical Sciences, University of Yaoundé I, PB 1364 Yaoundé, Cameroon
}

Correspondence should be addressed to Tchoula Mamiafo Corinne; tchoulacorinne@yahoo.fr

Received 10 April 2019; Revised 8 August 2019; Accepted 24 August 2019; Published 25 January 2020

Academic Editor: Yuksel Agca

Copyright (c) 2020 Tchoula Mamiafo Corinne et al. This is an open access article distributed under the Creative Commons Attribution License, which permits unrestricted use, distribution, and reproduction in any medium, provided the original work is properly cited.

\begin{abstract}
Objective. Hormones play a vital role in initiating and maintaining male reproductive function. The present study explores the influence and predictive ability of two reproductive hormones on semen quality among men who were partners in an infertile couple. Design. During our cross sectional study, men were recruited from private and public hospital and laboratories for clinical evaluation of fertility status. Methods. Fresh semen samples were assessed for quality (concentration, motility and morphology) according to the 2010 World Health Organization manual and the serum levels of hormones, including follicle-stimulating hormone (FSH), Inhibin B was measured (ELISA). Results. We found a significant difference in the two groups regarding sperm concentration $(p<0.0001)$, total sperm count $(p<0.0001)$, progressive motility $(p<0.0001)$, vitality $(p<0.0001)$ and the percentage of normal forms $(p=0.043)$. We found a strong and negative correlation between FSH and Inhibin B in the overall population, the normozoospermic reference group and the case group. Our study confirmed that Inhibin B was significantly and positively correlated with sperm concentration and leucocytes, and that FSH was negatively correlated to sperm concentration and vitality. Conclusion. Consistent with other studies, our results show strong association between semen quality and FSH and Inhibin B.
\end{abstract}

\section{Introduction}

Male infertility is found in $50 \%$ of infertile couples [1]. When reviewed, $55 \%$ of the reasons for infertility are found to be male-related and $35 \%$ to be female-related, while $10 \%$ constitutes infertility of unknown origin [2].

The etiology of declining male fertility can be related to falling androgen levels, decreased sexual activity, alterations in sperm motility and morphology, and deterioration in sperm quality and DNA integrity [3].

Previous studies have reported that circulating levels of specific reproductive hormones in men are associated with semen quality parameters [4]. In particular, Inhibin B and follicle-stimulating hormone (FSH) are thought to be markers of spermatogenesis and Sertoli cell function, and it has even been suggested that measuring the two hormones in serum could serve as a substitute for measuring semen quality or fecundability in epidemiologic studies [4].
Inhibin $\mathrm{B}$ is a heterodimeric glycoprotein composed of a common $\alpha$-subunit and a specific $\beta \mathrm{B}$-subunit [5]. In men, this protein is produced exclusively by the testis [5]. Inhibin B production is stimulated by the secretion of pituitary follicle-stimulating hormone (FSH). The resulting Inhibin B exerts a negative feedback on FSH secretion. Inhibin B also exerts a paracrine intratesticular effect [5]. The assessment of testicular function typically involves an initial endocrine assessment, in which serum FSH and total testosterone levels are routinely measured $[6,7]$. When measured, Inhibin B levels correlate quite well with FSH concentrations in the vast majority of cases. However, the diagnostic accuracy of FSH is limited by the fact that some conditions do not lead to changes in FSH secretion [5]. FSH and Inhibin B are complementary tools in gonadal male conditions and andrological diagnostics $[5,8]$. In particular, FSH and Inhibin B together are more sensitive than either alone in predicting the histological status of the testis and the presence of sperm in bioptic tissue [5]. 
This study is designed to study levels of follicle-stimulating hormone (FSH), and Inhibin B in blood serum, and their relation to seminal fluid functional parameters in a group of infertile patients.

\section{Material and Methods}

2.1. Subject Recruitment. The study population comprised healthy men referred for semen analysis to some private laboratories and health institutions. Our men subjects were members of infertile and fertile couples. For a given individual, the semen and blood samples were provided on the same day. All the participants gave their written informed consent.

2.2. Study Design. This cross-sectional study was carried out at six Public health institutions and Private laboratories of the Yaoundé Town. These centers are located in the political capital of Cameroon, and receive a large number of male patients living in Yaoundé and surrounding towns. A convenient sample of 240 infertile male patients, aged 18 years and above, were consecutively enrolled in the study during twelve months. But only 156 succeeded in providing both semen and blood samples. All the procedures used in this study were in accordance with the current revision of the Helsinki Declaration. A written and signed informed consent was provided by all the subjects. Consent forms and procedures, as well as survey protocol, were approved by the Cameroon National Ethics Committee (Reference number: 2015/04/572/CE/CNERSH/SP).

2.3. Interview Data. At enrollment standardized data collection forms were completed, including sociodemographic characteristics, the medical background, previous unions, chirurgical background, and sexuality.

2.4. Collection of Semen Samples. Semen was collected by masturbation into a sterile plastic specimen cup at the hospital or laboratory. Subjects were instructed to abstain from ejaculation for at least 72 hours prior to producing the semen sample. The actual abstinence period was recorded based on the information given by men at the time of the semen collection. The sample was liquefied for at least 30 minutes at $37^{\circ} \mathrm{C}$, but no longer than 1 hour prior to performing a routine semen analysis, which included measurements of volume, $\mathrm{pH}$, sperm concentration, sperm motility, progressive motility, and sperm morphology according to standard methodologies [9].

2.5. Evaluation of the Quality of Sperm. Before starting semen analysis, a period of time must be allowed for liquefaction. The normal liquefaction time is 30 minutes. If this is not done within this time, we will say that it is slow rather than normal. The semen volume, total sperm number, sperm concentration, motility, and vitality were interpreted according to the 2010 WHO guidelines.

Strict scoring criteria were used to classify men as having normal or subnormal morphology [9] as recommended by WHO guidelines. Kruger's classification identifies a single sperm anomaly. The anomaly is listed in order of importance as follows: acrosome, head, intermediate piece and flagella. As soon as an abnormality is identified, the spermatozoon is directly classified as "abnormal”.

2.6. Determination of Biochemical Parameters. Venous blood samples were taken from the cubital vein. The samples were left for $30 \mathrm{~min}$ at room temperature, then centrifuged at $3000 \mathrm{rpm}$ for 15 minutes at room temperature. The sera were transported to small Eppendorf tubes and stored at $-20^{\circ} \mathrm{C}$. The serum Inhibin B was determined in duplicate using the Inhibin B Gen II ELISA technic of Beckman Coulter (250 S. Kraemer Blvd. Brea, CA 92821 U.S.A.) which is an enzymatically amplified three-step "sandwich" assay. In the assay, calibrators, controls and samples are incubated in microtitration wells which have been coated with anti-activin B antibody [10]. Serum FSH levels were measured with a Microplate Immunoenzymometric assay of Monobind Inc. (IEMA/ELISA) (100 North pointe Drive, Lake Forest, CA 92630 U.S.A.).

2.7. Statistical Analysis. Data were coded and entered in Excel 2013, then analyzed using XLSTAT 2014. Semen parameters and hormone levels were expressed as the median $\left(5^{\text {th }}-95^{\text {th }}\right.$ percentiles). The Mann-Whitney U test was used to compare the reference and case groups.

Relationships between hormone levels and semen parameters were analyzed using Spearman's correlation test.

The evaluation of the parameters is based on the World Health Organization criteria.

Different aspects of semen analysis are discussed, such as enumeration of spermatozoa, viability, Kruger classification and interpretation of results.

Normozoospermia (reference group) corresponded to a total sperm count $\geq 20$ million/ejaculate, progressive motility $\geq 32 \%$ (as defined in the 2010 WHO manual), and normal forms $\geq 15 \%$ (as defined in our laboratory).

A $p$ value $<0.05$ was used to characterize significant results.

\section{Results}

3.1. Semen Characteristics and Hormone Level Distributions of the Study Population. We recruited a total of 240 men but only 156 of them actually provided blood and semen samples for analysis. Of these, 48 presented semen parameters within the reference limits and thus constituted the reference group (Normospermic). In contrast, 108 men presented at least one abnormal semen parameter (as defined above) and thus constituted the case group.

The mean age of our population was $37.101 \pm 7.371$ years and the majority classes were those aged 30-35 followed by those aged 40-45.

Our patients had on average one child and the type of infertility found was more secondary (53.846\%).

Table 1 presents the semen characteristics and hormone level distributions of our population. We found a significant difference in the two groups regarding sperm concentration $(p<0.0001)$, total sperm count $(p<0.0001)$, progressive motility $(p<0.0001)$, vitality $(p<0.0001)$ and the percentage of normal forms $(p=0.043)$. No statistical difference has been 
TABLE 1: Semen characteristics of the study population. Data are reported as the median $\left(5^{\text {th }}-95^{\text {th }}\right.$ percentiles $)$. Comparison between the reference group and the case group was performed using a Mann-Whitney $U$ test.

\begin{tabular}{|c|c|c|c|c|c|}
\hline Characteristics of the population & Overall population & Reference group & Case group & Normal values & $p$ \\
\hline Age (years) & $37(26-50)$ & $37.6(27-49.6)$ & $36.5(23.8-48.8)$ & NA & 0.385 \\
\hline Number of children & $1(0-4)$ & $1(0-4)$ & $1(0-5)$ & NA & 0.471 \\
\hline Abstinence (days) & $3(2-6)$ & $3(2-6)$ & $3(3-7)$ & $3-5$ days & 0.441 \\
\hline Semen volume $(\mathrm{mL})$ & $2.92(0.96-5.5)$ & $2.95(0.72-5.6)$ & $2.8(1.2-4.46)$ & $\geq 2 \mathrm{~mL}$ & 0.923 \\
\hline $\mathrm{pH}$ & $8.31(7.5-9)$ & $8.32(7.6-9)$ & $8.3(7.5-9)$ & $\geq 7,2$ & 0.594 \\
\hline Viscosity & $1(0-3)$ & $1(0-3)$ & $1(0-3)$ & 0 & 0.431 \\
\hline Sperm concentration (million/mL) & $14.8(0.2-70.2)$ & $10.8(0.03-54.6)$ & $39.6(2.1-78.8)$ & $\geq 20 \times 10^{6} / 1$ & $<\mathbf{0 . 0 0 0 1}$ \\
\hline Total sperm count (million/ejaculate) & $33(0-194.08)$ & $12.42(0-109.1)$ & $122.12(14.83-300.28)$ & $\geq 40 \times 10^{6}$ & $<0.0001$ \\
\hline Progressive motility (\%) & $43.2(2-76)$ & $35.3(0-72.6)$ & $64(45.6-80.6)$ & $\geq 50 \%$ & $<0.0001$ \\
\hline Vitality $(\%)$ & $53(10.8-85.2)$ & $45.8(9.4-81.4)$ & $72(56.4-86.6)$ & $\geq 50 \%$ & $<0.0001$ \\
\hline Normal forms (\%) & $85(67-94)$ & $84(65.8-94)$ & $87(74.8-92.6)$ & $\geq 85 \%$ & 0.043 \\
\hline
\end{tabular}

$p<0.05$ was considered to be statistically significant. The significant values are $p<0.0001$ and $p=0.043$.

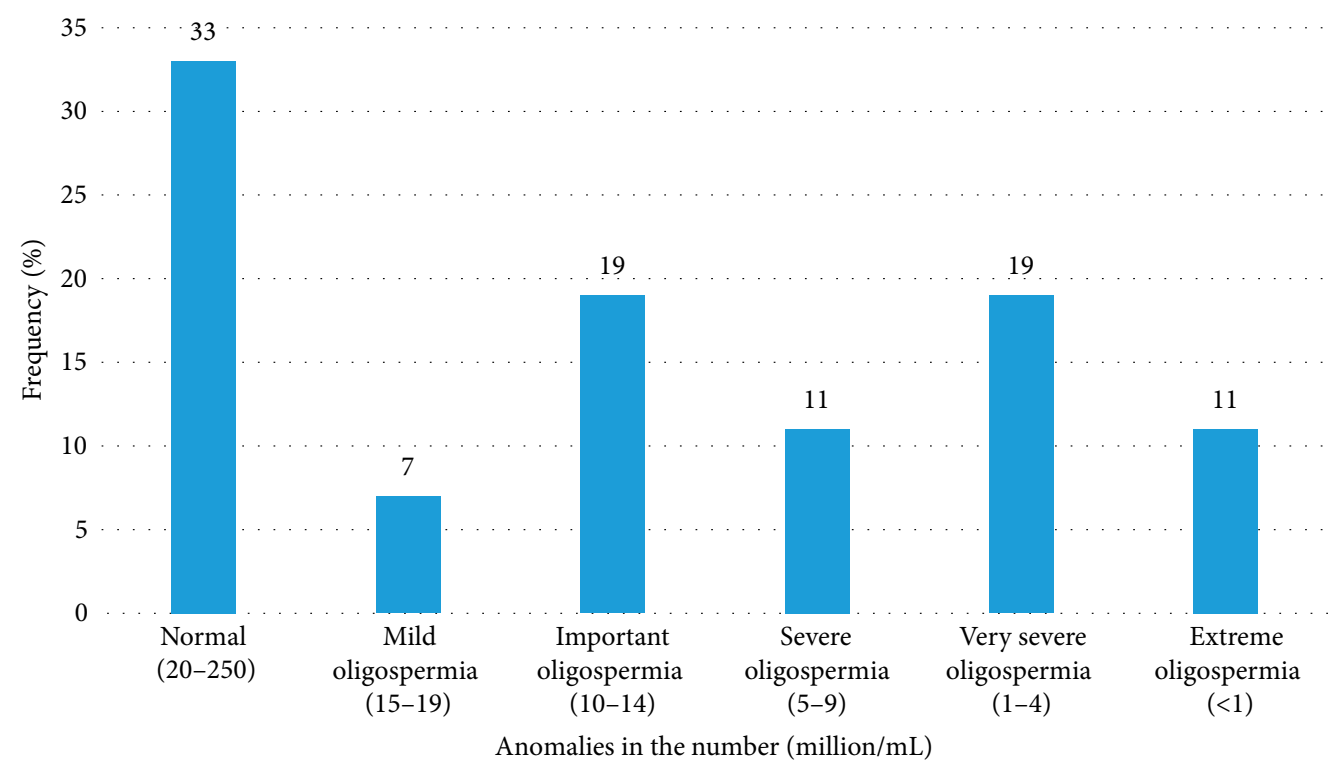

FIGURE 1: Distribution of the population according to anomalies in numbers.

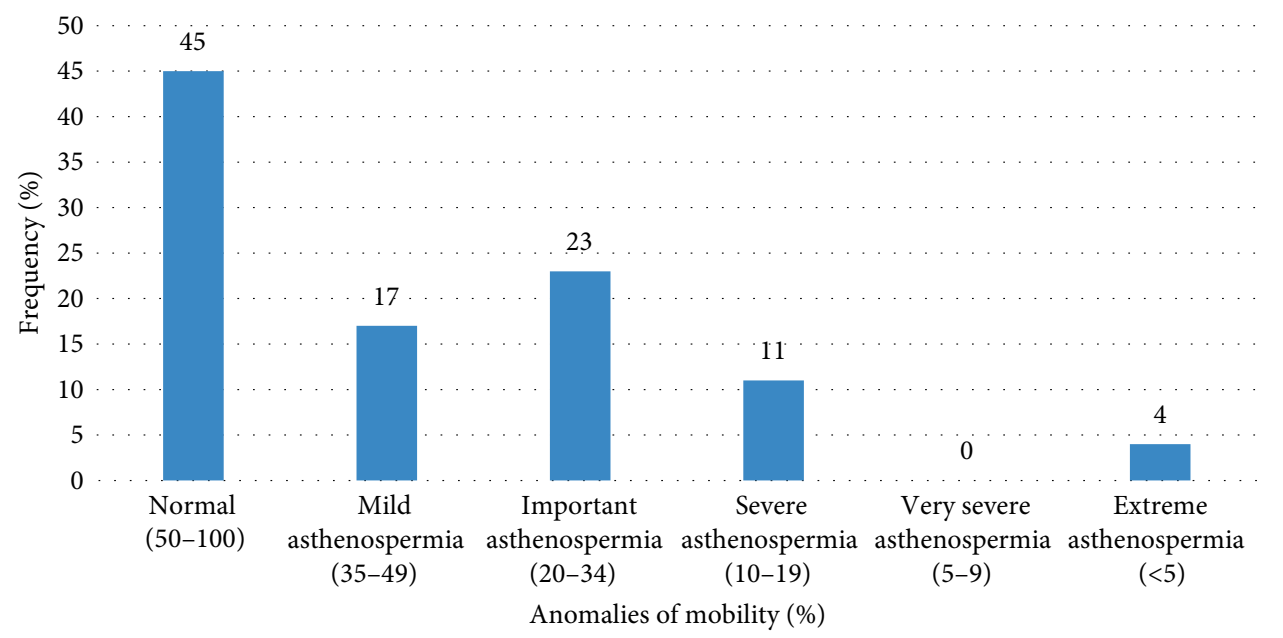

FIGURE 2: Distribution of the population according to mobility anomalies. 


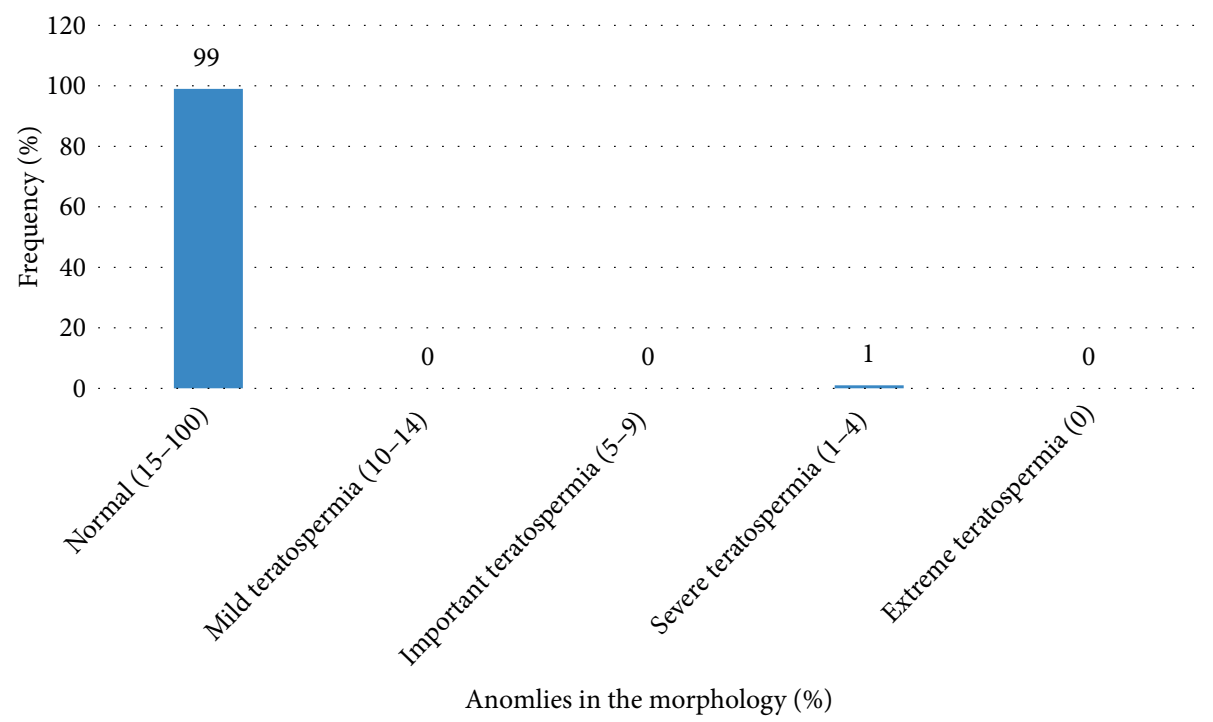

FIgURE 3: Distribution of the population based on morphology abnormalities.

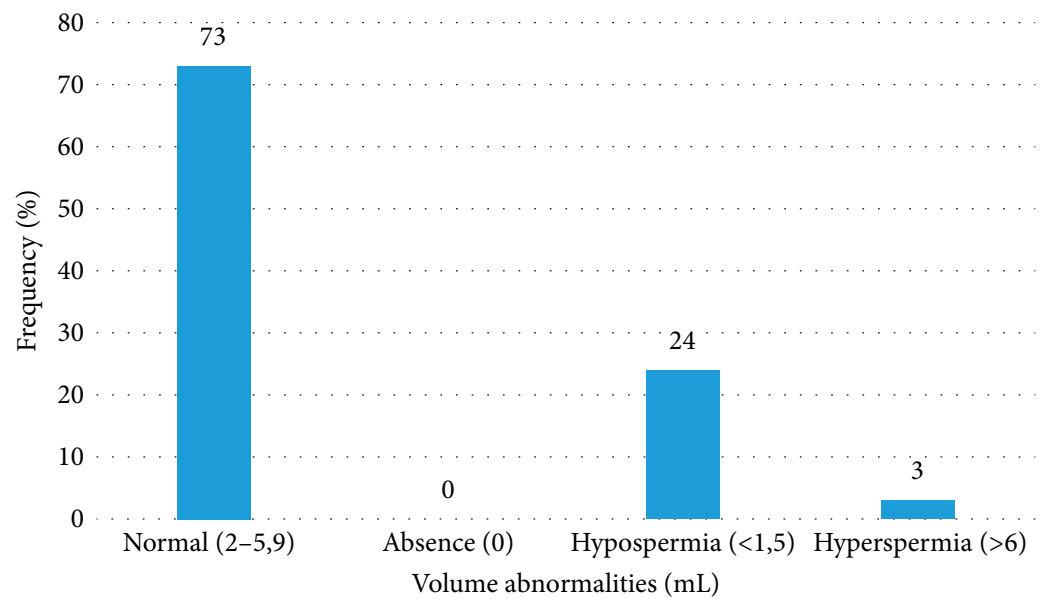

FIGURE 4: Distribution of the population according to volume anomalies.

TABLE 2: Distribution of the population according to the level of hormone FSH and Inhibin B.

\begin{tabular}{lcccc}
\hline $\begin{array}{l}\text { Characteristics of the } \\
\text { population }\end{array}$ & Overall population & Reference group & Case group & Normal values \\
\hline Inhibin B (pg/mL) & $139.1(10.33-373.72)$ & $153.2(44.5-389.7)$ & $125.94(9.8-311.44)$ & $\begin{array}{c}>30 \mathrm{pg} / \mathrm{mL} \\
\text { Young man: }<5 \mathrm{UI} / \mathrm{L} \\
\text { Adult: } 3-15 \mathrm{UI} / \mathrm{L}\end{array}$ \\
FSH (UI/L) & $5.53(0.2-29.4)$ & $3.78(0.1-34.93)$ & $6.63(0.24-28.62)$ & $\begin{array}{c}\mathbf{0 . 0 1 3} \\
\text { Andropause }(>40 \text { years): } \\
\text { 37-020 }\end{array}$ \\
\hline
\end{tabular}

$p<0.05$ was considered to be statistically significant. The significant values are $p=0.013$ and $p=0.020$ which is less than 0.05 .

found regarding age, number of children, days of abstinence, semen volume, $\mathrm{pH}$, and viscosity $(p>0.05)$.

Figure 1 presents the distribution of the population based on the anomalies in the number. It appears that in terms of frequency, patients with significant oligospermia were execo with those with very severe oligospermia (19\%).

Concerning mobility abnormalities, (Figure 2) shows that $23 \%$ of patients had significant asthenospermia, $17 \%$ a mild asthenospermia and $11 \%$ a severe asthenospermia.
The abnormalities of morphologies are presented in Figure 3 . We note that $99 \%$ of the patients had a normal sperm morphology.

The study of abnormalities in sperm volume (Figure 4) shows that $73 \%$ had a normal sperm volume, $24 \%$ were hypospermia, and $3 \%$ were hyperspermia.

Also, in a general point of view, about $46 \%$ of our infertile patients presented associations of the abnormalities cited above cited above (morphology, mobility, number and volume). 
TABLE 3: Relationship between hormone levels and semen parameters. Correlation was done using spearman correlation test.

\begin{tabular}{|c|c|c|c|}
\hline Semen parameters & Population & Inhibin $\mathrm{B}(r ; p)$ & $\mathrm{FSH}(r ; p)$ \\
\hline \multirow{3}{*}{ Semen volume $(\mathrm{mL})$} & Overall population & $0.139(0.096)$ & $-0.004(0.966)$ \\
\hline & Reference group & $0.528^{*}(p<0.0001)$ & $-0.284(0.051)$ \\
\hline & Case group & $0.058(0.553)$ & $0.065(0.504)$ \\
\hline \multirow{3}{*}{ Viscosity } & Overall population & $-0.049(0.562)$ & $0.024(0.779)$ \\
\hline & Reference group & $-0.045(0.761)$ & $0.102(0.488)$ \\
\hline & Case group & $-0.083(0.393)$ & $-0.006(0.949)$ \\
\hline \multirow{3}{*}{$\mathrm{pH}$} & Overall population & $-0.117(0.163)$ & $0.159(0.057)$ \\
\hline & Reference group & $-0.283(0.052)$ & $0.223(0.127)$ \\
\hline & Case group & $-0.110(0.258)$ & $0.152(0.116)$ \\
\hline \multirow{3}{*}{$\begin{array}{l}\text { Sperm concentration } \\
(\mathrm{million} / \mathrm{mL})\end{array}$} & Overall population & $0.183^{*}(0.028)$ & $-0.217^{*}(0.009)$ \\
\hline & Reference group & $0.043(0.771)$ & $-0.001(0.992)$ \\
\hline & Case group & $0.006(0.948)$ & $-0.113(0.243)$ \\
\hline \multirow{3}{*}{$\begin{array}{l}\text { Total sperm count } \\
\text { (million/ejaculate) }\end{array}$} & Overall population & $0.307^{*}(p<0.0001)$ & $-0.179^{*}(0.032)$ \\
\hline & Reference group & $0.245(0.093)$ & $-0.045(0.762)$ \\
\hline & Case group & $0.261^{*}(0.006)$ & $-0.197^{*}(0.041)$ \\
\hline \multirow{3}{*}{ Vitality (\%) } & Overall population & $0.103(0.219)$ & $-0.197^{*}(0.018)$ \\
\hline & Reference group & $-0.159(0.280)$ & $0.024(0.869)$ \\
\hline & Case group & $-0.056(0.565)$ & $-0.112(0.249)$ \\
\hline \multirow{3}{*}{ Progressive motility (\%) } & Overall population & $0.072(0.388)$ & $-0.152(0.069)$ \\
\hline & Reference group & $0.046(0.755)$ & $-0.062(0.674)$ \\
\hline & Case group & $-0.032(0.744)$ & $-0.036(0.709)$ \\
\hline \multirow{3}{*}{ Normal forms (\%) } & Overall population & $0.088(0.296)$ & $0.005(0.956)$ \\
\hline & Reference group & $0.041(0.780)$ & $0.064(0.664)$ \\
\hline & Case group & $-0.084(0.387)$ & $-0.010(0.922)$ \\
\hline \multirow{3}{*}{ Leucocytes } & Overall population & $0.227^{*}(0.006)$ & $0.025(0.764)$ \\
\hline & Reference group & $-0.103(0.486)$ & $-0.036(0.805)$ \\
\hline & Case group & $0.207^{*}(0.032)$ & $0.006(0.949)$ \\
\hline \multirow{3}{*}{ Red blood cells } & Overall population & $-0.073(0.386)$ & $-0.004(0.958)$ \\
\hline & Reference group & 1 & 1 \\
\hline & Case group & $-0.030(0.757)$ & $0.075(0.437)$ \\
\hline \multirow{3}{*}{ Round cells } & Overall population & $-0.027(0.747)$ & $-0.040(0.635)$ \\
\hline & Reference group & $-0.301^{*}(0.038)$ & $0.024(0.872)$ \\
\hline & Case group & $0.070(0.473)$ & $0.067(0.492)$ \\
\hline
\end{tabular}

Table 2 shows the hormonal distributions of our population. We found that FSH was significantly higher in the case group $(p=0.020)$. In contrast, the level of Inhibin B was lower in the case group $(p=0.013)$.

The analysis of the hormone concentrations according to the age classes have shown a great increase of FSH with years $(p<0.0001)$ and a decrease of Inhibin B concentration $(p=0.328)$.

3.2. Correlations between Hormone Levels and Semen Parameters. Relationship between hormone levels and semen parameters have been studied in Table 3 and we have noticed in the overall population, a positive correlation between Inhibin $B$ and sperm concentration $(p=0.028 ; r=0.183)$, total sperm count $(p<0.0001 ; r=0.307)$ and leucocytes $(p=0.006$; $r=0.227)$; while a negative correlation between FSH and sperm concentration $(p=0.009 ; r=-0.217)$, total sperm count $(p=0.032 ; r=-0.179)$ and vitality $(p=0.018 ; r=-0.197)$. In the reference group, we noted a positive correlation between Inhibin B and the volume $(p<0.0001 ; r=0.528)$ and a negative correlation between Inhibin B and the round cells $(p=0.038$; $r=-0.301)$. Finally, the case group showed positive correlation between Inhibin B and total sperm count $(p=0.006 ; r=0.261)$ and leucocytes and a negative correlation between FSH and the total sperm count ( $p=0.041 ; r=-0.197)$.

We found a strong and negative correlation between FSH and Inhibin B $(r=-0.477 ; p<0.0001)$ in the overall population, the normozoospermic group (reference group) $(r=-0.367 ; p=0.011)$, and the case group $(r=-0.511$; $p<0.0001)$.

We analyzed the relationship between semen parameters in our population. Table 4 shows that, in the overall population, positive correlation has been found between the volume and Total sperm count $(r=0.235)$ and leucocytes $(r=0.187)$; the sperm concentration and total sperm count $(r=0.636)$, vitality $(r=0.540)$, mobility $(r=0.551)$, red blood cells $(r=0.232)$, and 
TABLE 4: Relationship between semen parameters in the overall population. Correlation was done using spearman correlation test.

\begin{tabular}{|c|c|c|c|c|c|c|c|c|c|c|c|}
\hline Variables & $\begin{array}{l}\text { Volume } \\
(\mathrm{mL})\end{array}$ & Viscosity & $\mathrm{pH}$ & $\begin{array}{l}\text { Sperm con- } \\
\text { centration } \\
(\mathrm{spz} / \mathrm{ml})\end{array}$ & $\begin{array}{c}\text { Total sperm } \\
\text { count } \\
\text { (spz/ejaculate) }\end{array}$ & $\begin{array}{l}\text { Vitality } \\
(1 \mathrm{~h}) \%\end{array}$ & $\begin{array}{l}\text { Motility } \\
(1 \mathrm{~h}) \%\end{array}$ & $\begin{array}{l}\text { Normal } \\
\text { forms }\end{array}$ & $\begin{array}{c}\text { Leuco- } \\
\text { cytes }\end{array}$ & $\begin{array}{c}\text { Red } \\
\text { blood } \\
\text { cells } \\
\end{array}$ & $\begin{array}{l}\text { Round } \\
\text { cells }\end{array}$ \\
\hline $\begin{array}{l}\text { Volume } \\
(\mathrm{mL})\end{array}$ & 1 & -0.087 & $-0.215^{*}$ & -0.122 & $0.235^{*}$ & 0.138 & 0.160 & 0.097 & $0.187^{*}$ & -0.065 & -0.005 \\
\hline Viscosity & -0.087 & 1 & 0.063 & -0.025 & -0.033 & -0.027 & -0.037 & -0.122 & $-0.192^{*}$ & 0.005 & -0.087 \\
\hline $\mathrm{pH}$ & $-0.215^{*}$ & 0.063 & 1 & -0.136 & $-0.185^{*}$ & -0.058 & -0.069 & 0.121 & -0.110 & -0.043 & -0.091 \\
\hline $\begin{array}{l}\text { Sperm } \\
\text { concentra- } \\
\text { tion } \\
(\mathrm{spz} / \mathrm{ml})\end{array}$ & -0.122 & -0.025 & -0.136 & 1 & $0.636^{*}$ & $0.540^{*}$ & $0.551^{*}$ & 0.076 & $-0.199^{*}$ & $0.232^{*}$ & $0.232^{*}$ \\
\hline $\begin{array}{l}\text { Total sperm } \\
\text { count (spz/ } \\
\text { ejaculate) }\end{array}$ & $0.235^{*}$ & -0.033 & $-0.185^{*}$ & $0.636^{*}$ & 1 & $0.525^{*}$ & $0.520^{*}$ & $0.249^{*}$ & $0.238^{*}$ & $-0.391^{*}$ & -0.161 \\
\hline $\begin{array}{l}\text { Vitality } \\
(1 \text { h) \% }\end{array}$ & 0.138 & -0.027 & -0.058 & $0.540^{*}$ & $0.525^{*}$ & 1 & $0.969^{*}$ & $0.267^{*}$ & 0.044 & -0.026 & 0.116 \\
\hline $\begin{array}{l}\text { Motility } \\
(1 \mathrm{~h}) \%\end{array}$ & 0.160 & -0.037 & -0.069 & $0.551^{*}$ & $0.520^{*}$ & $0.969^{*}$ & 1 & $0.269^{*}$ & 0.020 & -0.018 & 0.148 \\
\hline $\begin{array}{l}\text { Normal } \\
\text { forms }\end{array}$ & 0.097 & -0.122 & 0.121 & 0.076 & $0.249^{*}$ & $0.267^{*}$ & $0.269^{*}$ & 1 & $0.231^{*}$ & $-0.194^{*}$ & -0.114 \\
\hline Leucocytes & $0.187^{*}$ & $-0.192^{*}$ & -0.110 & $-0.199^{*}$ & $0.238^{*}$ & 0.044 & 0.020 & $0.231^{*}$ & 1 & $-0.525^{*}$ & $-0.226^{*}$ \\
\hline $\begin{array}{l}\text { Red blood } \\
\text { cells }\end{array}$ & -0.065 & 0.005 & -0.043 & $0.232^{*}$ & $-0.391^{*}$ & -0.026 & -0.018 & $-0.194^{*}$ & $-0.525^{*}$ & 1 & $0.614^{*}$ \\
\hline Round cells & -0.005 & -0.087 & -0.091 & $0.232^{*}$ & -0.161 & 0.116 & 0.148 & -0.114 & $-0.226^{*}$ & $0.614^{*}$ & 1 \\
\hline
\end{tabular}

$p<0.05$ was considered to be statistically significant. ${ }^{*}$ Significant. All the values marked with asterix $\left({ }^{*}\right)$ are significant $(p<0.05)$.

TABLE 5: Relationship between semen parameters in the reference group. Correlation was done using spearman correlation test.

\begin{tabular}{|c|c|c|c|c|c|c|c|c|c|c|}
\hline Variables & $\begin{array}{l}\text { Volume } \\
(\mathrm{mL})\end{array}$ & Viscosity & $\mathrm{pH}$ & $\begin{array}{l}\text { Sperm con- } \\
\text { centration } \\
(\mathrm{spz} / \mathrm{ml})\end{array}$ & $\begin{array}{c}\text { Total } \\
\text { sperm } \\
\text { count (spz/ } \\
\text { ejaculate) }\end{array}$ & $\begin{array}{l}\text { Vitality } \\
(1 \mathrm{~h}) \%\end{array}$ & $\begin{array}{l}\text { Motility } \\
(1 \mathrm{~h}) \%\end{array}$ & $\begin{array}{l}\text { Normal } \\
\text { forms }\end{array}$ & $\begin{array}{c}\text { Leuco- } \\
\text { cytes }\end{array}$ & $\begin{array}{l}\text { Round } \\
\text { cells }\end{array}$ \\
\hline $\begin{array}{l}\text { Volume } \\
(\mathrm{mL})\end{array}$ & 1 & -0.078 & -0.051 & 0.003 & $0.286^{*}$ & 0.006 & 0.142 & 0.037 & 0.071 & -0.151 \\
\hline Viscosity & -0.078 & 1 & 0.007 & -0.118 & -0.095 & 0.082 & 0.087 & -0.145 & -0.184 & 0.001 \\
\hline $\mathrm{pH}$ & -0.051 & 0.007 & 1 & $-0.349^{*}$ & $-0.296^{*}$ & 0.115 & 0.002 & 0.200 & 0.038 & 0.124 \\
\hline $\begin{array}{l}\text { Sperm } \\
\text { concentra- } \\
\text { tion (spz/ } \\
\text { ml) }\end{array}$ & 0.003 & -0.118 & $-0.349^{*}$ & 1 & $0.793^{*}$ & -0.051 & 0.110 & -0.129 & 0.115 & -0.010 \\
\hline $\begin{array}{l}\text { Total sperm } \\
\text { count (spz/ } \\
\text { ejaculate) }\end{array}$ & $0.286^{*}$ & -0.095 & $-0.296^{*}$ & $0.793^{*}$ & 1 & -0.245 & -0.031 & -0.087 & 0.208 & 0.007 \\
\hline $\begin{array}{l}\text { Vitality } \\
(1 \text { h) } \%\end{array}$ & 0.006 & 0.082 & 0.115 & -0.051 & -0.245 & 1 & $0.799^{*}$ & -0.211 & -0.027 & 0.211 \\
\hline $\begin{array}{l}\text { Motility } \\
(1 \text { h) } \%\end{array}$ & 0.142 & 0.087 & 0.002 & 0.110 & -0.031 & $0.799^{*}$ & 1 & -0.072 & 0.104 & 0.267 \\
\hline $\begin{array}{l}\text { Normal } \\
\text { forms }\end{array}$ & 0.037 & -0.145 & 0.200 & -0.129 & -0.087 & -0.211 & -0.072 & 1 & -0.045 & -0.113 \\
\hline Leucocytes & 0.071 & -0.184 & 0.038 & 0.115 & 0.208 & -0.027 & 0.104 & -0.045 & 1 & $0.654^{*}$ \\
\hline Round cells & -0.151 & 0.001 & 0.124 & -0.010 & 0.007 & 0.211 & 0.267 & -0.113 & $0.654^{*}$ & 1 \\
\hline
\end{tabular}

$p<0.05$ was considered to be statistically significant. ${ }^{*}$ Significant.All the values marked with asterix $\left({ }^{*}\right)$ are significant $(p<0.05)$.

round cells $(r=0.232)$; the total sperm count and vitality $(r=0.525)$, motility $(r=0.520)$, normal forms $(r=0.249)$, and leucocytes $(r=0.238)$; the vitality and mobility $(r=0.969)$ and normal forms $(r=0.267)$; the motility and normal forms $(r=0.269)$; the normal forms and leucocytes $(r=0.231)$; the red blood cells and round cells $(r=0.614)$. On the other hand, we observed a negative correlation between the volume and $\mathrm{pH}$ $(r=-0.215)$; the sperm concentration and leucocytes $(r=-0.199)$; the total sperm count and $\mathrm{pH}(r=-0.185)$ and red blood cells ( $r=-0.391)$; the normal forms and red blood cells 
TABLE 6: Relationship between semen parameters in the case group. Correlation was done using spearman correlation test.

\begin{tabular}{|c|c|c|c|c|c|c|c|c|c|c|c|}
\hline Variables & $\begin{array}{l}\text { Volume } \\
(\mathrm{mL})\end{array}$ & Viscosity & $\mathrm{pH}$ & $\begin{array}{l}\text { Sperm con- } \\
\text { centration } \\
(\mathrm{spz} / \mathrm{ml})\end{array}$ & $\begin{array}{c}\text { Total } \\
\text { sperm } \\
\text { count (spz/ } \\
\text { ejaculate) }\end{array}$ & $\begin{array}{l}\text { Vitality } \\
(1 \mathrm{~h}) \%\end{array}$ & $\begin{array}{l}\text { Motility } \\
(1 \text { h) } \%\end{array}$ & $\begin{array}{l}\text { Normal } \\
\text { forms }\end{array}$ & $\begin{array}{c}\text { Leuco- } \\
\text { cytes }\end{array}$ & $\begin{array}{l}\text { Red } \\
\text { blood } \\
\text { cells }\end{array}$ & $\begin{array}{l}\text { Round } \\
\text { cells }\end{array}$ \\
\hline $\begin{array}{l}\text { Volume } \\
(\mathrm{mL})\end{array}$ & 1 & -0.072 & $-0.235^{*}$ & -0.109 & $0.193^{*}$ & 0.101 & 0.121 & 0.084 & $0.191^{*}$ & -0.054 & 0.043 \\
\hline Viscosity & -0.072 & 1 & 0.061 & 0.059 & -0.005 & 0.084 & 0.043 & -0.131 & $-0.214^{*}$ & 0.013 & -0.112 \\
\hline $\mathrm{pH}$ & $-0.235^{*}$ & 0.061 & 1 & -0.021 & -0.179 & -0.083 & -0.072 & $0.194^{*}$ & $-0.206^{*}$ & -0.051 & -0.078 \\
\hline $\begin{array}{l}\text { Sperm } \\
\text { concentra- } \\
\text { tion } \\
(\mathrm{spz} / \mathrm{ml})\end{array}$ & -0.109 & 0.059 & -0.021 & 1 & $0.597^{*}$ & $0.367^{*}$ & $0.420^{*}$ & 0.070 & $-0.258^{*}$ & 0.146 & 0.153 \\
\hline $\begin{array}{l}\text { Total sperm } \\
\text { count (spz/ } \\
\text { ejaculate) }\end{array}$ & $0.193^{*}$ & -0.005 & -0.179 & $0.597^{*}$ & 1 & $0.347^{*}$ & $0.407^{*}$ & 0.141 & 0.145 & $-0.313^{*}$ & -0.125 \\
\hline $\begin{array}{l}\text { Vitality } \\
(1 \text { h) \% }\end{array}$ & 0.101 & 0.084 & -0.083 & $0.367^{*}$ & $0.347^{*}$ & 1 & $0.904^{*}$ & 0.089 & -0.079 & 0.059 & 0.112 \\
\hline $\begin{array}{l}\text { Motility } \\
(1 \mathrm{~h}) \%\end{array}$ & 0.121 & 0.043 & -0.072 & $0.420^{*}$ & $0.407^{*}$ & $0.904^{*}$ & 1 & 0.163 & -0.111 & 0.045 & 0.142 \\
\hline $\begin{array}{l}\text { Normal } \\
\text { forms }\end{array}$ & 0.084 & -0.131 & $0.194^{*}$ & 0.070 & 0.141 & 0.089 & 0.163 & 1 & 0.146 & -0.111 & -0.109 \\
\hline Leucocytes & $0.191^{*}$ & $-0.214^{*}$ & $-0.206^{*}$ & $-0.258^{*}$ & 0.145 & -0.079 & -0.111 & 0.146 & 1 & $-0.392^{*}$ & -0.158 \\
\hline $\begin{array}{l}\text { Red blood } \\
\text { cells }\end{array}$ & -0.054 & 0.013 & -0.051 & 0.146 & $-0.313^{*}$ & 0.059 & 0.045 & -0.111 & $-0.392^{*}$ & 1 & $0.626^{*}$ \\
\hline Round cells & 0.043 & -0.112 & -0.078 & 0.153 & -0.125 & 0.112 & 0.142 & -0.109 & -0.158 & $0.626^{*}$ & 1 \\
\hline
\end{tabular}

$p<0.05$ was considered to be statistically significant. ${ }^{*}$ Significant. All the values marked with asterix $\left({ }^{*}\right)$ are significant $(p<0.05)$.

$(r=-0.194)$; the red blood cells and leucocytes $(r=-0.525)$; the leucocytes and round cells $(r=-0.226)$ and viscosity $(r=-0.192)$.

As shown in Table 5, in the reference population the correlation between semen parameters showed a positive correlation between volume and total sperm count $(r=0.286)$; the total sperm count and sperm concentration $(r=0.793)$; the vitality and motility $(r=0.799)$; leucocytes and round cells $(r=0.654)$. We also noticed a negative correlation between $\mathrm{pH}$ and sperm concentration $(r=-0.349)$ and total sperm count $(r=-0.296)$.

Concerning the correlation between semen parameters in the case group (Table 6), it appears a positive correlation between volume and the total sperm count $(r=0.193)$ and the leucocytes $(r=0.191)$; the $\mathrm{pH}$ and normal forms $(r=0.194)$; the sperm concentration and total sperm count $(r=0.597)$, vitality $(r=0.367)$ and motility $(r=0.420)$; the total sperm count and vitality $(r=0.347)$ and motility $(r=0.407)$; the red blood cells and round cells $(r=0.626)$; vitality and motility $(r=0.904)$. We also found a negative correlation between the $\mathrm{pH}$ and volume $(r=-0.235)$ and leucocytes $(r=-0.206)$; Leucocytes and viscosity $(r=-0.214)$; total sperm count and red blood cells $(r=-0.313)$; sperm concentration and leucocytes $(r=-0.258)$; Leucocytes and red blood cells $(r=-0.392)$.

\section{Discussion}

Previous studies have reported that circulating levels of specific reproductive hormones in men are associated with sperm quality parameters [4]. In particular, Inhibin B and FSH are considered markers of Sertoli spermatogenesis and cell function. It has even been suggested that measurement of both hormones in serum may be a substitute for measuring sperm quality or fecundability in epidemiological studies [4].

The current study analyzes blood levels of Inhibin B and FSH and their relationship with semen parameters.

In line with previous studies $[11,12,22-29]$ we found that the infertile men's group was older than the reference group (with majority age classes from 30 to 35 followed by 40 to 45). This is probably the age at which men feel the need to start a family. More than $58 \%$ of our population had an advanced age of paternity ( $>35$ years). In addition, we observed a great increase of FSH with years and a decrease of Inhibin concentration. The literature describes a positive and significant correlation between age and number of children, duration of infertility and marital status. This could be explained by the fact that as men age, testicular function and metabolism deteriorate when the testes undergo age-related morphological changes such as decreased germ cell counts, Leydig cells, and Sertoli, as well as structural changes, including shrinkage of seminiferous tubules [30, 31].

In men inhibin is secreted from the testis as a product of Sertoli cells involved in the regulation of FSH secretion [33]. We found a strong and negative correlation between FSH and Inhibin B in the overall population, the case and the reference group. This corroborates very well the findings of Barbotin et al. [5], Jensen et al. [32], and Von Eckardstein et al. [33], stating that FSH and Inhibin B are complementary tools in gonadal male conditions and andrological diagnostics [5]. In 
particular, FSH and Inhibin B together are more sensitive than either alone in predicting the histological status of the testis and the presence of sperm in bioptic tissue [5]. FSH which is a gonadotropin that is produced and secreted by the anterior pituitary, acts on Sertoli cells in the seminiferous tubules to initiate spermatogenesis. Sertoli cells secrete Inhibin B, which is a protein hormone. Thus, as found in our study, an association between Inhibin B and sperm concentration was to be expected, since the regulation of both factors is dependent upon Sertoli cell function $[4,5,14]$.

In the overall population and the case group, Inhibin B was significantly and positively correlated with sperm concentration while FSH was negatively correlated to sperm concentration. We could not observe this correlation in the normospermic group. These findings confirmed those of Jorgensen et al. in 2010 [15], Kumanov et al. in 2006 [16], Myers et al. in 2008 [17], Sikaris et al. in 2005 [18] and Grunewald et al. in 2013 [19]. Moreover, Barbotin et al. explained that associations between hormone levels and sperm count are stronger in studies of the general population [32, $34]$ or infertile men $[4,16,17,35]$ than in studies of fertile men $[15,17]$. They were precise that it could be due to the marked interindividual differences in sperm count seen in populations of primarily normozoospermic and/or fertile men. In total, categories of men (fertile, infertile, and normozoospermic) represented overlap in semen qualities, suggesting that Inhibin B and FSH were not mainly markers of fertility but rather markers of semen quality and thereby fecundity. In addition, It has been suggested that Inhibin B may be a better predictor of spermatogenesis than FSH [33]. The clinical value of the Inhibin B assay is emphasized by the fact that in contrast to $\mathrm{FSH}$, Inhibin B is produced inside the testis and might reflect close interactions between Sertoli and germ cells [33]. Thus, Inhibin B levels correlate directly with spermatogenesis and reflect testicular sperm production.

Although the known association between sperm motility and sperm concentration [17], we could not observe in our population a correlation between sperm motility and Inhibin $\mathrm{B}$ and FSH levels but we did observe the correlation between sperm concentration and vitality and mobility both in the overall population and the case group but not in the normospermic group. Considering their overall population, Tomlinson et al. [20] and Karabulut et al. [21] also found a strong correlation between the sperm concentration, the motility and the morphology. Our results are different from Barbotin et al. who observed in their population a relationship between sperm motility and Inhibin B and FSH levels. But just like us they found a strong relationship between sperm concentration and vitality and mobility both in the overall population and the case group but not in the normospermic group. This could be explained by the fact that they included a very large number of individuals compared to our sample size.

\section{Conclusion}

At the end of this study, our results showed lower values of semen parameters in the case group especially concerning the sperm concentration, the progressive motility, the vitality, and the percentage of normal forms.
The correlation of Inhibin B and FSH to the sperm parameters highlights their role as markers of spermatogenesis. The combination of FSH and Inhibin B is currently the best predictor of the presence of spermatozoa.

\section{Data Availability}

The biological data used to support the findings of this study are available from the corresponding author upon request.

\section{Conflicts of Interest}

There is no conflict of interest regarding any of the authors.

\section{Authors' Contributions}

Study concept and design: Ngogang Yonkeu Jeanne, Pieme Constant Anatole, and Tchoula Mamiafo Corinne. Data collection: Tchoula Mamiafo Corinne. Statistical analysis: Tchoula Mamiafo Corinne. Drafting: Tchoula Mamiafo Corinne. Manuscript revision: Ngogang Yonkeu Jeanne, Pieme Constant Anatole and Tchoula Mamiafo Corinne. Study supervision: Ngogang Yonkeu Jeanne.

\section{Acknowledgments}

This research did not receive any specific grant from any funding agency in the public, commercial or not-for-profit sector.

\section{References}

[1] T. G. Cooper, E. Noonan, S. von Eckardstein et al., "World Health Organization referencevalues for human semen characteristics," Human Reproduction, vol. 16, pp. 231-245, 2010.

[2] L. Speroff and M. A. Fritz, "Female infertility, Chapter 27," Clinical Gynecologic Endocrinology and Infertility, Lippincott Williams \& Wilkins, 8th edition, 2010, syf: 1157.

[3] G. Sartorius and E. Nieschlag, "Paternal age and reproduction," Human Reproduction, vol. 16, pp. 65-79, 2010.

[4] J. D. Meeker, L. Godfrey-Bailey, and R. Hauser, "Relationships between serum hormone levels and semen quality among men from an infertility clinic," Journal of Andrology, vol. 28, no. 3, pp. 397-406, 2007.

[5] A.-L. Barbotin, C. Ballot, J. Sigala et al., "The serum Inhibin B concentration and reference ranges in normozoospermia," European Journal of Endocrinology, vol. 172, pp. 669-676, 2015.

[6] B. D. Anawalt, "Approach to male infertility and induction of spermatogenesis," Journal of Clinical Endocrinology and Metabolism, vol. 98, no. 9, pp. 3532-3542, 2013.

[7] Practice Committee of American Society for Reproductive Medicine, "Diagnostic evaluation of the infertile male: a committee opinion," Fertility and Sterility, vol. 98, no. 2, pp. 294-301, 2012.

[8] V. Mitchell, G. Robin, F. Boitrelle et al., "Correlation between testicular sperm extraction outcomes and clinical, endocrine and testicular histology parameters in 120 azoospermic men with normal serum FSH levels," International Journal of Andrology, vol. 34, pp. 299-305, 2011. 
[9] Word Health Organization (WHO), Laboratory Manual for the Examination of Human Semen and Sperm-Cervical Mucus Interaction, University Press, Cambridge, 4th edition, 1999.

[10] H. Ludlow, S. Muttukrishna, M. Hyvönen, and N. P. Groome, "Development of a new antibody to the human inhibin/activing betaB subunit and its application to improvement Inhibin B ELISAs," Journal of Immunological Methods, vol. 329, no. 1-2, pp. 102-111, 2008.

[11] V. Subramanian, A. Ravichandran, N. Thiagarajan, M. Govindarajan, S. Dhandayuthapani, and S. Suresh, "Seminal reactive oxygen species and total antioxidant capacity: Correlations with sperm parameters and impact on male infertility," Clinical and Experimental Reproductive Medicine, vol. 45, no. 2, pp. 88-93, 2018, pISSN 2233-8233, eISSN 2233-8241.

[12] Q. A. Makarim, S. A. Rana, and F. Muhammad-Baqir, "Relationship between lipid peroxidation and integrity of sperm plasma membrane in a sample of iraqi infertile men IOSR," Journal of Pharmacy and Biological Sciences (IOSR-JPBS), vol. 12, no. 6 Ver. I, pp. 19-27, 2017.

[13] C. D. Okafor, S. C. Meludu, K. Nwaefulu, J. I. Ikechebelu, C. E. Dioka, and U. Obi, "Comparison of serum oxidative stress markers among male partners of fertile and infertile couple at Nnamdi Azikiwe University Teaching Hospital, Nnewi, Anambra State," Nigeria Journal of Scientific and Innovative Research, vol. 6, no. 4, pp. 126-128, 2017.

[14] F. H. Pierik, J. T. M. Vreeburg, T. Stijnen, F. H. De Jong, and R. F. A. Weber, "Serum Inhibin B as a marker of spermatogenesis," Journal of Clinical Endocrinology and Metabolism, 2006, jcem. endojournals.org at Medical Library Erasmus MC on December 11, 0021-972X/98/\$03.00/0.

[15] N. Jorgensen, F. Liu, A. M. Andersson et al., "Serum inhibin-b in fertile men is strongly correlated with low but not high sperm counts: a coordinated study of 1,797 European and US men," Fertility and Sterility, vol. 94, no. 6, pp. 2128-2134, 2010.

[16] P. Kumanov, K. Nandipati, A. Tomova, and A. Agarwal, "Inhibin $\mathrm{B}$ is a better marker of spermatogenesis than other hormones in the evaluation of male factor infertility," Fertility and Sterility, vol. 86, no. 2, pp. 332-338, 2006.

[17] G. M. Myers, G. M. Lambert-Messerlian, and M. Sigman, "Inhibin B reference data for fertile and infertile men in Northeast America," Fertility and Sterility, vol. 92, pp. 19201923, 2009.

[18] K. Sikaris, R. I. McLachlan, R. Kazlauskas, D. de Kretser, C. A. Holden, and D. J. Handelsman, "Reproductive hormone reference intervals for healthy fertile young men: evaluation of automated platform assays," Journal of Clinical Endocrinology and Metabolism, vol. 90, pp. 5928-5936, 2005.

[19] S. Grunewald, H.-J. Glander, U. Paasch, and J. Kratzsch, "Agedependent Inhibin B concentration in relation to FSH and semen sample qualities: a study in 2448 men," Reproduction, vol. 14, no. 5, pp. 237-244, 2013.

[20] M. J. Tomlinson, O. Moffatt, G. C. Manicardi, and D. Sakkas, "Interrelationships between seminal parameters and sperm nuclear DNA before and after density gradient centrifugation: implication for assisted conception. European society of human Reproduction and Embryology," Human Reproduction, vol. 16, no. 10, pp. 2160-2165, 2001.

[21] S. Karabulut, I. Keskin, and Y. Sagıroglu, "Relationship between semen parameters in samples obtained from sub-fertile," Andrology (Los Angel), vol. 6, no. 1, 2017.
[22] F. Atig, A. Kerkeni, A. Saad, and M. Ajina, "Effects of reduced seminal enzymatic antioxidants on sperm DNA fragmentation and semen quality of Tunisian infertile men," Journal of Assisted Reproduction and Genetics, vol. 34, no. 3, pp. 373-381, 2017.

[23] A. Mehrotra, D. K. Katiyar, A. Agarwal, V. Das, and K. K. Pant, "Role of total antioxidant capacity and lipid peroxidation in fertile and infertile men," Biomedical Research-India, vol. 24, pp. 347-352, 2013.

[24] M. A. El-Taieb, M. A. Ali, and E. A. Nada, "Oxidative stress and acrosomal morphology: a cause of infertility in patients with normal semen parameters," Middle East Fertility Society Journal, vol. 20, no. 2, pp. 79-85, 2015.

[25] T. Kullisaar, S. Turk, K. Kilk, K. Ausmees, M. Punab, and R. Mandar, "Increased levels of hydrogen peroxide and nitric oxide in male partners of infertile couples," Andrology, vol. 1, no. 6, pp. 850-858, 2013.

[26] S. Benedetti, M. C. Tagliamonte, S. Catalani et al., "Differences in blood and semen oxidative status in fertile and infertile men, and their relationship with sperm quality," Reproductive BioMedicine Online, vol. 25, no. 3, pp. 300-306, 2012.

[27] Y. Gao, Y. Gao, L. Du, Z. Qin, and Z. Hu, “Zinc, lead, cadmium, malondialdehyde contents and superoxide dismutase activity in serum and seminal plasma in male infertility patients," Journal of Reproductive Medicine, vol. 21, pp. 43-46, 2012, Article in Chinese.

[28] M. B. Shamsi, R. Kumar, N. Malhotra et al., "Chromosomal aberrations, Yq microdeletion, and sperm DNA fragmentation in infertile men opting for assisted reproduction," Molecular Reproduction and Development, vol. 79, no. 9, pp. 637-650, 2012.

[29] O. Alejandro, A. Spira, and L. Multigner, "Contribution of environmental factors to the risk of male infertility," Human Repoduction, vol. 16, no. 8, pp. 1768-1776, 2001.

[30] S. Gunes, G. N. Hekim, M. A. Arslan, and R. Asci, “ Effects of aging on the male reproductive system," Journal of Assisted Reproduction and Genetics, vol. 33, no. 4, pp. 441-454, 2016.

[31] D. Durairajanayagam, “Lifestyle causes of male infertility, Arab Journal of Urology, vol. 16, no. 1, pp. 10-20, 2018.

[32] T. K. Jensen, A. M. Andersson, N. H. Hjollund et al., "Inhibin B as a serum marker of spermatogenesis: correlation to differences in sperm concentration and follicle-stimulating hormone levels. A study of 349 Danish men," Journal of Clinical Endocrinology and Metabolism, vol. 82, no. 12, pp. 4059-4063, 1997.

[33] S. Von Eckardstein, M. Simoni, M. Bergmann et al., "Serum Inhibin B in combination with serum follicle-stimulating hormone (FSH) is a more sensitive marker than serum FSH alone for impaired spermatogenesis in men, but cannot predict the presence of sperm in testicular tissue samples," Journal of Clinical Endocrinology and Metabolism, vol. 84, pp. 2496-2501, 1999.

[34] M. L. Uhler, M. J. Zinaman, C. C. Brown, and E. D. Clegg, "Relationship between sperm characteristics and hormonal parameters in normal couples," Fertility and Sterility, vol. 79, pp. 1535-1542, 2003.

[35] F. H. Pierik, A. Burdorf, F. H. de Jong, and R. F. Weber, "Inhibin B: a novel marker of spermatogenesis," Annals of Medicine, pp. 3512-3520, 2003. 